\title{
School Library Management in Private Junior High Schools
}

\author{
Dyah Rakhmayanti, Soedjarwo, Karwanto \\ Department of Educational Management \\ Universitas Negeri Surabaya \\ Surabaya, Indonesia \\ dyah.18001@mhs.unesa.ac.id
}

\begin{abstract}
School library, as an information unit will have a good performance if it has adequate management. This study used a qualitative approach with multi-site study design. The data were collected through in-depth interviews, observations, and documentation studies. The results of this study are as follows: (1) school library planning is determined by participatory, appropriate processing of library materials, procurement planning of library materials based on bottom-up need analysis, publication activity, funding, and excellent service for visitors; (2) organization of the school library is determined by the availability of organization structure, job division, authority division, command unity, and definite coordination; (3) the success of school library implementation is determined by participatory, the direction and motivation from leader to subordinates, healthy communication and awarding to librarians; and (4) evaluation of the school library is determined by the availability of complete and comprehensive periodic written reports.
\end{abstract}

Keywords-school library management; planning; organization; implementation; evaluation

\section{INTRODUCTION}

School library is an important part of the education components that cannot be separated from the school environment. This is due to the fact that the school library functions as a means of supporting students' learning activities to achieve the learning goals.

The importance of the school library can be seen in Law of the Republic of Indonesia no 23 No. 20 of 2003 concerning the National Education System, Chapter XII Educational Facilities and Infrastructure, article 45 paragraph 1 which states "Every formal and non-formal education unit provides facilities and infrastructure that meet educational needs in accordance with the growth and development of physical, intellectual, social, emotional, and psychological potential of learners. "

In that article, it is explained that one of the important, but not the only, learning resources is a library that allows educators and students to get the opportunity to widen and deepen their knowledge by reading library materials needed to improve the quality of education. As other organizations, school library also needs management of achieve their goals of helping improve the quality of students' and teachers' knowledge, skills, values, and attitudes in improving their selfquality.

Hartono state that management is one of the studies of what and how that can be done, both through theory and practice, so that libraries, documentation, and information can be managed efficiently and effectively [6]. These resources are managed through a management process that includes planning, organizing, implementation or leadership, and evaluation or supervision expected to be able to generate products in the form of goods or services.

Based on observations made in other schools, nowadays, many schools are still unable to carry out management functions properly. Many school libraries do not have vision and mission, work program, and schedule for learning in the library. These libraries have an organizational structure, but the division of labour and responsibility/authority does not go well because the head of the library and the administrative officers are teachers who do not understand the management of school libraries. Besides that, the ratio of the number of students and library officers is not comparable. Therefore, the library cannot develop well. In its implementation, periodic guidance of school leaders is not carried out by school leaders or committee members, therefore, the school library seems to be an independent organization without any direction and guidance from school stakeholders. Similarly, the principal does not regularly evaluate the head of the library, whereas the head of the library does not make any final report on library activities during the school year. This makes the desired goal difficult to achieve because the implementation does not have clear guidelines and tends to be poorly managed.

Library management that does not work well is a major problem experienced by school libraries. The results of previous studies [2], [10], [12], [3], and [20] that have revealed various inhibiting factors for the development of school libraries. These inhibiting factors include: a) the existence of schools that still do not have a school library, b) implementation of library leadership that is still not optimal, c) the scarcity of proper library buildings and lack of reading materials, d) the limitation of school fund causing building construction and space arrangement were not optimal, and the purchase of non-fiction and fiction book collection became very limited, and e) services for users who are still unsatisfactory. A study on successful school library 
management needs to be conducted as a model for other schools to immediately have proper management as well.

In Surabaya, there are private junior high schools that have successfully manage their school library. One of the indicators of the chosen schools as research sites is their achievement as the first winner of the library competition. In addition, the two school libraries are unique in that they were built in a large area and have more than 20.000 titles, IT-based administrations, stakeholder support, and services toward the digital library.

The description above shows that service management implemented in private school libraries is optimized prime. Library as a learning resource at focus on the interests of visitors especially for students and teachers at school that is. Based on a preliminary study the writer is interested in conduct research on school library management with multi-site study at private Junior High Schools.

Based on the background of the research above, there are four focus of the research, namely: 1) the planning of school library at private Junior High Schools, 2) the organizing of school library at private Junior High Schools, 3) The implementation of school library at private Junior High Schools, and 4) The evaluation of school library at private Junior High Schools.

Therefore, a study needs to be conducted immediately of which the results can be used as a model for other schools to carry out proper, effective, and efficient library management.

Bafadal [8] stated that the management of school libraries is all business coordinating all activities related to the implementation of school libraries. School library management is an effort to utilize all school resources, namely human resources, systems, and funding sources in the activities of planning, organizing, implementing, and evaluating to make school library achieve its objectives.

The school library planning is the process of activities in preparing targets and resources needed in a certain period of time for the future in accordance with the tasks and functions set to achieve the objectives of the library [6]. In planning school library management, it is necessary to plan the following matters: the determination of vision and mission, processing of library materials, planning of sourcebook and other material procurement, planning of visitor increase, planning of budget increases and service improvements.

The school library organizing is a unification of steps in all activities to be carried out by the institution elements. Setting this step is important so that there is no overlap in the task implementation [4]. This organizing process will work well when paying attention to organizational principles as the basis of motion, namely: division of labor, division of authority, unity of command, and coordination.

The school library implementation is a combination of several interconnected management functions which includes leadership, direction, communication, giving motivation as well as providing facilities and infrastructure [4].

Rahmah [4] state that the school library evaluation is a process to ensure that all activities carried out in the library are in accordance with the planned set. Evaluation in library organizations is to find out whether the work carried out in the library runs effectively and efficiently and if an error occurs it can be corrected immediately. Evaluation can be done by asking for reports on the results of the implementation of activities in accordance with the plans made.

\section{METHOD}

This study used a qualitative approach because the focus of this research is more about processes, understanding human behavior from the frame of reference of the actors themselves and requiring in-depth observation with natural settings.

The design of this study was a multi-site study due to the involvement of several sites/locations and research subjects. The research location is in Surabaya. The research subjects were assumed to have the same characteristics, namely: 1) the two schools are junior high school (SMP) education units; and 2) the institutional status is a private school. This multi-site study was begun with a single site analysis, followed by crosssite analysis to integrate and compare results generated from the entire site, preparation of final research results, and conclusions

The subjects of this study consisted of principals, deputy principal in the curriculum, deputy principal in the field of public relations, deputy principals in infrastructure, library head, librarians, teachers, and students. There was a total of 17 informants. Data collection through in-depth interviews, observation, and documentation studies and the data is in the form of field notes, documents, photography, and statistical data.

The validity check used three of four criteria, namely: (1) credibility, (2) dependability, and (3) confirmability.

\section{RESULTS AND DISCUSSION}

The multi-site study conducted at the private junior high school lasted approximately 3 months. The focus of this research on the functions of school library management is planning, organizing, implementation, and evaluation of the school library in private junior high school. The following are the research results and discussion of school library management in private junior high schools in Surabaya:

\section{A. School Library Planning}

In the School library planning, there are several activities carried out by the school libraries namely:

First, the libraries did library planning at the beginning of the new school year in a bottom-up manner. In addition, the vision and mission of the library are socialized to the school community through the library website and/or banner displayed in the library room.

Second, the school libraries processed library materials including stamps, DDC classifications, inventory, labeling or barcoding, book covering, data input into computers, and book collection arrangement on shelves.

Third, school libraries procured library materials. The procurement of library materials through needs analysis in a 
bottom-up manner. The needs analysis was carried out by the schools included checking existing collections by librarians, distributing library order questionnaires to teachers, employees and students as well as searching catalogs from publishers and the internet, and then buying library materials from publishers or bookstores.

Fourth, school libraries published and promoted libraries through library websites and bibliographies. there are schools that already have library websites so that users can search book collections through the website and complete the library collection with articles and e-books. But there are also schools that do not yet have their own library websites so that publications / promotions are still through a bibliographies posted at several locations in the school.

Fifth, school libraries carried out the financial management of the budget provided by the foundation and the principal as well as from fines or students' infaq (donation). Financial management in the library is carried out by the head of the library and librarians. The libraries have a definite budget each year.

Sixth, school libraries had carried out circulation services (loans and returns) and applied sanctions to book borrowers who are late in returning library materials with the aim of enforcing discipline to the school community. There are schools that apply sanctions in the form of money and there are schools that apply sanctions in the form of confiscation of goods that students like or sanctions in the form of reprimand and advice.

Based on the findings above, it can be seen that the school library planning in private schools is appropriate. library management theory states that the first step in school library planning is the determination of vision, mission, goals, identification of strengths and weaknesses, and understanding opportunities and threats. In the library, planning is made by taking into account the various interests of the parties who will be involved in implementing the activity [4]. By participating in the planning, personnel's commitment to the implementation of education will be higher, their ideals are increasing, they are hand in hand doing the task, and love for work [1]. so that it can provide work directions and work guidelines for librarians in carrying out activities in the library. Similarity, Perrin [9] argues that unit level strategic plans can help libraries by giving individuals specific goals that are tailored to their strengths and make up for the unit's weaknesses.

In its implementation, the activity of processing library materials in schools can vary the sequence of activities or process flow. This may be caused by differences in work culture, human resources and infrastructure in the processing process. But, processing library materials is supported by Darmanto [17] who explained that there are four steps to processing library materials that must be carried out including 1) inventory, 2) classification, 3) cataloguing, and 4) shelving.

After that the library procures libraries and develops library collections. It through needs analysis in a bottom-up manner. Collection development is a systematic process in building a strong and directed library collection in accordance with the needs of users. Library collection development activities include 1) surveying user needs and processing survey data, 2) compiling a list of user needs, 3) collecting library material selection tools, 4) distributing selection tasks among representatives from their respective subject areas, 5) selection of titles, 6) preparation of desiderata files, and 7) making a list of proposals for procurement of library materials according to the selection results arranged based on priority information needs by paying attention to available funds [6].

To get the attention of the school community, the library needs to do a promotion. Library promotion aims to introduce libraries, collections, types of services and benefits obtained by library users. The private school libraries published and promoted libraries through library websites and bibliographies. Schools that already have a significant library budget, services through the website and electronic books are very interesting because the users demand almost instant service for time efficiency in this digital era [6]. Similarity, Chen [7] said with development of network technology, the library should offer personalized service for readers, and the library should develop in the direction of intelligent. The readers can obtain the interest resources at any time and in any place. The paper and electronic books should give satisfactory service for readers, and the analytic hierarchy process is applied in evaluating the personalized service level of library information management of library, and the simulation analysis results show the effectiveness of this method. Similarity, $\mathrm{Xu}$ and Guo [5] states that libraries can provide effective wireless communication for student learning and research, and ultimately give students an impressive library experience.

Even so, promotion strategies carried out by school libraries should be more varied and interesting. According to Hartono [6] the form of promotional activities can be through 1) printed forms, namely brochures, posters, new letters, bookmarks, guidebooks, library calendars and 2) forms of promotional activities namely exhibitions, lectures and seminars, storytelling, bazaars, competition and quiz, library tours, and film screenings. To support promotional and publication activities, the library also fostered collaboratio with other schools in the form of lending library materials to be photocopied and librarian assistance [6].

For procurement and development of collections, the libraries have a definite budget each year. The library budget is in accordance with the mandate of the library law, which is at least $5 \%$ of the school operational budget. this is in accordance with the research conducted by Harahap [21] that purchases collections in the library of Muhammadiyah I Middle School in Depok Yogyakarta is quite a lot, especially in budgeting for school funds spent $10 \%$ of the BOS funds provided by the government. This makes that the school has exceeded the standards described on Republic of Indonesia Law No. 43/2007 concerning the library, in article 23 paragraph 6 written that use a minimum of $5 \%$ of the BOS funds for library development. In buying the collection the school fully mandates to librarians to buy collections based on agreed upon and required to make a report on what has been 
done. Collection type purchased are enrichment books that support the learning process based on the school curriculum.

The success of the library is not only seen from the many library collections it has, but also must be accompanied by the provision of varied services for the sake of implementing the teaching and learning process and recreation for students. Micle [15] state that librarian usually provide traditional services. Therefore the negative attribute must be changed to a positive attribute by the development of new communication and information technologies thus allowing the re-invention of library identity through information culture, management policies, spaces, access to collections and services.

Private schools have provided services to users, but services are still limited to circulation services (loans and returns). This circulation service includes registration of loans, loan procedures, time of borrowing and collection of fines. The application of fines to users due to the loss of books or damage to books does need to be applied. This aims to instil discipline in the library and librarians so that the circulation of books can be carried out as fairly as possible among readers, especially if the collection is still small. The amount of the fine varies from one material to another and is adjusted to the school's culture [6].

Other types of services also needed to be developed by school libraries, because library services are the main activity in the library so that the more types of service provided by the library, the more fulfilled the needs of the school community [8]. Services needed to be developed by libraries are: a) information services; b) research services; c) recreational services; d) circulation services; e) reference services; f) literature search; g) user guidance; h) making library analysis; i) making service statistics; and j) storytelling services or children's games. The library do not only provides sources of information in academics, but also can help students improve their competence and potential, for example see [18].

\section{B. School Library Organizing}

There are several activities carried out by the school libraries namely:

First, they have a library organizational structure and a clear division of labor.

Two, the heads of library delegate authority according to the librarians' character and ability.

Third, orders to librarians only came from the head of the library. If there is an order from an outside party, it must be authorized by the head of the library. Likewise, all problems related to the library must be known and authorized by the head of the library.

Fourth, the heads of school library formally conduct coordination with library officers, principals, other school units and school community through regular meetings and non-formal meetings through daily communication.

Based on the findings above, school libraries have an organizational structure. The organizational structure shows the division of labour and how the different functions or activities are integrated (coordination) [4].

In carrying out their responsibilities, the head of the private school library delegates authority to his subordinates. Partial delegation of authority to subordinates is required to carry out specific work [4]. Delegation of authority based on the ability and the librarians' character is the right choice. This is in line with the suggestion of Pangastuti, Santoso and Hamidi [19] in which stated that delegation is done so that managers can develop subordinates' ability to strengthen the organization, especially in the event of a change in management.

So also the authority to govern librarians. Orders to librarians only came from the head of the library. If there is an order from an outside party, it must be authorized by the head of the library. In a good organizational system, there must be one-way command so that there is no confusion at the implementation level. Therefore, in the organizational system of the school library, it is necessary to avoid the dualism of influence and authority at various managerial levels. Therefore, the librarians' authority must be clear and to what extent the authority of librarian appointed as the head of the school library [4].

Finally, the head of school library have done coordination. it is important for school libraries to unite steps, reduce the clash of tasks, and reduce the incidence of internal conflicts. As a process, organizations highlight interactions between the people in them. This interaction can lead to formal and informal relationships. Formal relations between people in the organization have been regulated in the legal basis detailing the organizational structure and relationships that are hierarchical in nature and are usually reflected in the organizational structure chart. Informal relationships are not regulated and are not visible in the organizational structure [4], [11].

\section{School Library Implementation}

In School Library Implementation, there are several activities carried out by the school libraries namely:

First, the heads of school library always involve librarians in making policy related to libraries and providing rewards in the form of praise and material to those who have good performance.

Second, the librarians will give orders and directions to librarians verbally and non-formally if in carrying out their duties they experience difficulties.

Third, the library heads always create healthy communication with their subordinates through understanding the staffs' personal character and life or creating a fresh and humorous atmosphere.

Fourth, library heads always provide motivation for their staffs. Motivation in the form of encouraging advice, praise, and material or comparative studies.

Fifth, library heads conduct performance assessments of librarians. The results of the performance evaluation will be a reference for stakeholders to determine awards to librarians. 
The library is a whole unit led by a library head who must meet several qualifications in order to advance his library. Based on the findings above, policy making involving librarians will strengthen the implementation of the policy because of the support and contributions provided by the parties involved in it [16]. The application of democratic leadership is characterized by the existence of a structure whose development uses a cooperative decision-making approach which means employers reject all forms of competition and superiors can work with employees in making decisions. Giving rewards to librarians is one of the efforts of moral development so that librarians are always motivated to improve their performance [1]. Bridges [10] states that a library head is not just thinking about physical facilities, but also has to give thought about library leadership with regard to complexity, the importance of leadership, and real joy in making a difference in one's life. Similarity, Spear [14] state that a school librarian is a manager. Chief among her responsibilities is teaching but she also supervises people, collections, and spaces. Management skills are critical to a school librarian's succes.

In the context of the school library, the direction is the responsibility of the head of the library. In other words, the role of a leader is really needed in encouraging the staff he leads so that they can work as optimally as possible to achieve the desired goals [13]

In the work environment, the head of the library has managed to establish good and healthy communication with his subordinates. According to Abraham Maslow's motivational theory, after security needs are met, individuals need group communication and interaction with pleasant relationships and the creation of a good sense of cooperation. Thus respect and respect for individuals can be created [4]. Similarity, Khatibah [11] states that effective communication in library institutions is usually dyadic communication, communication with two or more people with various information and try to create one meaning in communicating, and the last effective communication is communication that can share meanings between communicators with communicants, and communicators can change communicant attitudes or behaviours. Although interpersonal communication or public communication sometimes is used. Therefore, without communication, cooperation in an organization cannot be done.

As with communication, motivation is a librarian's needs that must be met by the leader of the school library. Library heads must be able to motivate all staff in the implementation of work by: a) improving the performance of subordinates by analyzing their strengths and weaknesses, providing training, developing skills, developing work plans, and setting work performance goals, b) monitoring internal and external forces that can affecting the organization including performance indicators, financial and socio-cultural conditions, and c) coordinating and consulting and following developments in the community [6].

Private school library heads have conducted performance assessments of librarians. This is one of the tasks and responsibilities of the head of the school library, namely conducting an assessment of the organization of the school library [8]. Giving awards to librarians is one of the efforts to develop their moral so that they are always motivated to improve their performance.

\section{School Library Evaluation}

In School Library Evaluation, the heads of school library make written monthly and annual reports and have statistics on the development of collections and visitors. Making reports aims to describe the overall implementation of the school library and implement predetermined policies and procedures in the library [4].

\section{CONCLUSION}

\section{A. School Library Planning}

The success of school library planning is determined by participatory (involving library officers, principals, teachers, employees, and students), processing appropriate library materials, planning library procurement based on needs analysis, doing various publication/promotion activities, funding certainty and providing excellent service to visitors.

B. School Library Organization

The success of organizing a school library is determined by the existence of an organizational structure clearly, division of labor, division of authority, unity of command and clear coordination.

\section{School Library Implementation}

The success of the implementation of the school library is determined by participatory (involvement of librarians in policy making), the direction and motivation of leaders to subordinates, healthy communication and awarding to librarians.

D. School Library Evaluation

The success of evaluating the school library is determined by the existence of periodic written reports and statistical data that describe the implementation of a complete and comprehensive school library.

\section{REFERENCES}

[1] A.W. Rosyidi, "Pengaruh Gaya Kepemimpinan terhadap Kinerja Pustakawan pada Perpustakaan perguruan Tinggi Negeri di Surabaya," Journal Universitas Airlangga, unpublished.

[2] BF. Umar, "Managing school library services for effective academic performance and customer services in Nigeria," AJOL (African Journal On Line), Vol. 10 , No. 1, 2013, in press.

[3] E. Jaya PU, "Management of Senior High School Libraries (A Case Study of A-accredited Senior High Schools in Pontianak)," Socia Journal of Social Science, Vol. 14, No.1, pp. 8-14, 2017.

[4] E. Rahmah, Marlini, and G. Erlianti, Manajemen Perpustakaan. Depok: Rajawali Pers, 2018.

[5] G. F. Xu and J. X. Guo, "Improving Library User Experience: Wi-Fi Network Assessment," Journal of Library Administration, 58:8, 806834, 2018.

[6] Hartono, Manajemen Perpustakaan profesional. Jakarta : Sagung Seto, 2016.

[7] H. Chen, "Evaluation of Personalized Service Level for Library Information Management Based on Fuzzy Analytic Hierarchy Process," Procedia Computer Science, 131:952-958, 2018. 
[8] I. Bafadal, Pengelolaan Perpustakaan Sekolah, Jakarta : Rosdakarya, 2015.

[9] J. M. Perrin, " Strategic Planning From the Bottom Up: A Unit Strategic Plan That Pushes Change," Journal of Library Administration, 57:6, 712-722, 2017.

[10] K. Bridges, "Leadership Reflections: It is Not About the Perks," Journal of Library Administration, 59:6,656-662, 2019.

[11] Khatibah, "Komunikasi Pustakawan". Jurnal Iqra' IAIN SU, Vol. 8 , No.1, 2014, in press.

[12] L. Wickramanayake, "Where to from Here? Current Status of School Libraries in Sri Lanka," Ingenta Connect Journal, Vol. 117, No. 3-4, pp. 214-228 (15), 2016, in press.

[13] Mansyur, "Manajemen perpustakaan Sekolah," Surabaya : Pustakaloka, Vol. 7, No. 1, 2015, in press.

[14] M. J. Spear, "Reflections on Managing a School Library," Journal of library administration, 58:503-518, 2018.

[15] M. Micle, "Stereotypes Regarding Libraries and Librarians: An Approach of Romanian School and Academic Libraries," Procedia Social and Behavioral Sciences, 163:92 - 98, 2014.

[16] N. Mc. Auliffe, N. S. Bostain and A. D. Witchel, "The Relationship Between Authentic Leadership, Trust, and Engagement in Library Personnel, “ Journal of Library Administration, 59:2, 129-148, 2019.

[17] P. Darmanto, Manajemen Perpustakaan. Jakarta : Bumi Aksara, 2018.

[18] S. Milton and Q. H. Meade, "More Than Just a Student Voice: Facilitating Student Leadership Development Through the Library Student Liaison Program," Journal of Library Administration, 58:4, 346363, 2018.

[19] S.D. Pangastuti, S. Santosa, and N. Hamidi, "Pengaruh pendelegasian Wewenang dan Pembagian Kerja terhadap Prestasi Kerja karyawan BTN Surakarta. JUPE UNS Surakarta ," Vol. 2, No. 2, pp. 26-36, 2013, in press.

[20] T. Cottrell, "Good Libraries are Expensive Libraries?, " Ingenta Connect Journal, Vol. 26, No. 2, pp. 47-51 (5), 2013, in press

[21] W. R. Harahap, "Modernisasi Akuisisi Koleksi Perpustakaan," JIPI (Jurnal Ilmu Perpustakaan dan Informasi), Vol. 3 No. 1, 2018.

[22] Yin, Robert K., Qualitative Research from Start to Finish, New York : The Guildford Press, 2011. 